THE POLITICS OF POPULATION IN BRAZIL 
The Texas Pan American Series 


\section{THE POLITICS OF POPULATION IN BRAZIL}

\section{Elite Ambivalence and Public Demand}

by Peter McDonough and Amaury DeSouza

University of Texas Press - Austin and London 
Copyright (C) 1981 by the University of Texas Press

All rights reserved

Printed in the United States of America

Requests for permission to reproduce material from this work should be sent to Permissions, University of Texas Press, Box 7819, Austin, Texas 78712.

\section{Library of Congress Cataloging in Publication Data}

\section{McDonough, Peter, 1939-}

The politics of population in Brazil.

(The Texas Pan American series)

Bibliography: $p$.

Includes index.

1. Brazil-Population policy-Public opinion. 2. Birth control-BrazilPublic opinion. 3. Public opinion-Brazil. 4. Elite (Social sciences)-Brazil-Attitudes.

I. Sousa, Amaury de, joint author. II. Title.

HB3563.M33 304.6'6'0981 80-20490

ISBN 0-292-76466-9

The Texas Pan American Series is published with the assistance of a revolving publication fund established by the Pan American Sulphur Company.

This book was written under the auspices of the Institute for Social Research, The University of Michigan, and the Instituto Universitário de Pesquisas do Rio de Janeiro, Brazil. 